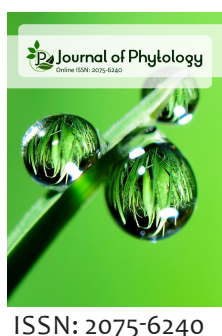

ISSN: $2075-6240$

\title{
Effect of enriched Sanjeevani and Agnihotra on growth, yield and quality of brinjal (Solanum melongena L.)
}

\author{
Saswatik Tripathy* and Avijit Kr. Dutta \\ Ramakrishna Mission Vivekananda Educational and Research Institute School of Agriculture and Rural \\ Development, F/C: IRTDM Ramakrishna Mission Ashrama, Morabadi, Ranchi-834008, Jharkhand, India
}

\begin{abstract}
Brinjal is a crop grown widely all over India and preferred by both rich and poor. The Chhotanagpur plateau of Jharkhand is famous for quality vegetable production and brinjal is very commonly grown in this region almost throughout the year. However, the most of the commercial growers using plant protection chemicals and synthetic fertilizers those are so expensive that poor farmers can't afford. The extensive uses of agro-chemicals and synthetic fertilizers also reduce the quality of both the produce and the cultivated soil. In this context, an attempt has been made through the present investigation by growing different varieties of brinjal by adopting Vedic (Enriched Sanjeevani) Farming and Homa Induction (Agnihotra) techniques with their respective four non-chemical alternative growing approaches, viz. $\mathrm{E}_{1} \mathrm{C}_{1}$ : Enriched Sanjeevani (1\%), $\mathrm{E}_{1} \mathrm{C}_{2}$ : Absolute Control (inherent fertility status of the experimental plot); $\mathrm{E}_{2} \mathrm{C}_{1}$ : Enriched Sanjeevani $(1 \%)+$ Homa Induction (Agnihotra), and $\mathrm{E}_{2} \mathrm{C}_{2}$ : Only Homa Induction (Agnihotra). Five varieties of the crop, viz. $V_{1}$ : Swarna Pratibha; $V_{2}$ : Swarna Neelima; $V_{3}$ : Swarna Shakti; $V_{4}$ : Mukta Jhuri; $V_{5}$ : Long Green were grown with their four replications under four growing conditions and the Randomized Completed Block Design was adopted for field trials. Different growth, yield and quality attributing characters of the crop were taken into account and findings revealed that $\mathrm{E}_{2} \mathrm{C}_{1}$ : Enriched Sanjeevani $(1 \%)$ + Homa Induction (Agnihotra) was the most suitable growing condition for $\mathrm{V}_{2}$ (Swarna Neelima) with the maximum yield $\left(72.37 \mathrm{tha}^{-1}\right)$. Different growth and yield attributes of the crop varieties (especially in the case of $\mathrm{V}_{2}$ : Swarna Neelima) were highly influenced by Enriched Sanjeevani (1\%) + Homa Induction (Agnihotra) $\left[\mathrm{E}_{2} \mathrm{C}_{1}\right]$ growing condition resulting higher benefit cost ratio of 6.78. Quality contributing attributes were also highly influenced by homa induction (Agnihotra), as a consequence, higher level of dry matter, TSS, and ascorbic acid contents were estimated from almost all samples collected from $\mathrm{E}_{2} \mathrm{C}_{1}$ : Enriched Sanjeevani $(1 \%)+$ Homa Induction (Agnihotra), and $\mathrm{E}_{2} \mathrm{C}_{2}$ : Only Homa Induction (Agnihotra) growing conditions.
\end{abstract}

*Corresponding Author:

Saswatik Tripathy

Email: tsaswatik.st@gmail.com

\section{INTRODUCTION}

Brinjal or eggplant (Solanum melongena L.) is a member of the family Solanaceae and it is an herbaceous annual with an erect or semi-spreader branching in nature. The fruit of brinjal is a berry grows individually or in clusters. It is grown commonly in almost all parts of the country and liked by both poor and the rich community. India is considered as the primary centre of origin and diversity of brinjal (Patil et al., 2008). Brinjal is a nutritious vegetable with short growth duration but it requires more chemical fertilizer especially nitrogenous ones and pesticides. Huge amount of agro-chemicals causes severe health hazard and affect fertility status of soils. A report reads about 355,000 people die globally every year for the poisoning of different agrochemicals especially pesticides and two third of the global death due to chemical farming is from the developing countries like India (Sharon and Nishanthlalu, 2014). This problem can only be overcome by the traditional organic farming, the concept of which was started 10000 years ago in the Vedic age. At that time the chemicals were not there but they can protect their plant, they can grow their food and can feed their people. After independence as well as partition the amount of land divided but the populations of India do not decrease at the same ratio of the land. As a result food scarcities arise. After World War-II, the countries who stop their business of weapons they started the business of chemical fertilizer, and they choose the Trans Gangetic plain as their place of extension and so called green revolution started through HYVP (High Yielding Variety Programme). The high yielding variety needs more fertilizer, more water as a result today Trans Gangetic plain become an unfertile land. The organically produced liquid manures can rejuvenate those areas. An organic liquid formulations namely Sanjeevani (here, Enriched Sanjeevani) is a substance which

Copyright: $\odot$ The authors. This article is open access and licensed under the terms of the Creative Commons Attribution License (http://creativecommons.org/licenses/by/4.0/) which permits unrestricted, use, distribution and reproduction in any medium, or format for any purpose, even commercially provided the work is properly cited. Attribution - You must give appropriate credit, provide a link to the license, and indicate if changes were made. 
make the soil immortal. Enriched Sanjeevani is one of the basic liquid manures consist of cow dung, cow urine, water, molasses and farm soil. Mix those in proper ratios (generally, 1:1:10 proportions of cow dung: Cow urine: water and one handful of garden soil and $50 \mathrm{~g}$ of molasses are sufficient for each kilogram of cow dung). The mixture is required to dilute 10 times before application in soil after three days of fermentation and 200 liter of Enriched Sanjeevani is sufficient for one acre of land. From only making of two liters mother solution we can easily meet the need for one acre, because the recommended dose of Enriched Sanjeevani is 1\%. Homa farming is the advanced organic farming, an alternative farming technique, in which an additional basic homa (Agnihotra) is done daily twice at the time of sunrise and sunset with any recommended organic package. According to the ancient science of homa, plants take $30 \%$ nutrients from the soil and $70 \%$ from its atmosphere. Homa farming is not only to provide nutrients through the atmosphere, it is the healing process of the atmosphere which is disturbed and become unhealthy to the human and plants due to the pollution. The ash of the Agnihotra is very good for soil and can be used to maintain the $\mathrm{pH}$ in any liquid or solid manure. The ash increases the water soluble phosphorus in the soil and basically it helps in mobilizing the nutrient. After a detailed study it is find that under the homa condition the chlorophyll of the plants are increased, and those are the main cause of the faster growth and yield maximization. But till now it is not clear that how the mechanism of burning organic substance in semi pyramid copper pot is effecting the chlorophyll growth (Berk and Jhonson, 2009). Pathak (2009) suggested to realize the possibility of integration of few techniques of organic farming for their synergistic impact and coined new term Homa Jaivik Krishi. This has compelled to conceive an organic production system, which is capable of enhancing rhizosphere and biosphere simultaneously which are popularizing today as "Homa Jaivik Krishi" (Pathak and Ram, 2010). Different alternative approaches of farming practices, especially organic farming has greater role over growth, yield and quality of brinjal. In this context, different researchers realized singnificant effect of organic manures in the forms of vermicompost, poultry manure, cow dung etc. over yield and quality traits of brinjal or other crops as well as soil physicochemical properties (Singh, 2004; Ullah et al., 2008; Mahto and Dutta, 2018).

\section{MATERIALS AND METHODOLOGY}

The present experiment was carried out at the organic experimental plot of Integrated Rural \& Tribal Development and Management Faculty Centre under the School of Agriculture and Rural Development of Ramakrishna Mission Vivekananda Educational and Research Institute, Morabadi, Ranchi (Latitude: 23023'59"N, Longitude: 85.20'15"E) during rabi-summer season of 2017-2018 under temperature regimes of $26^{0}-42^{\circ} \mathrm{C}$ (Max.) and $14^{0}-27^{\circ} \mathrm{C}$ (Min.) with the mean of $19^{\circ}-$ $33^{\circ} \mathrm{C}$. Five varieties of brinjal were exposed to grow through two non-chemical growing approaches, viz. Vedic and Agnihotra Farming. For Vedic Farming enriched Sanjeevani was taken as plant nutrient source. Sanjeevani with its enriched formulation was prepared by using cow dung, cow urine and water with their 1:1:10 proportion mixture and one handful of garden soils and
$50 \mathrm{~g}$ of molasses were added for each one $\mathrm{kg}$ of cow dung. The mixture was allowed to ferment for three days and thereafter the mixture was diluted 10 times with plain water before applying in the crop. As the Agnihotra may affect the crop up to one acre radius, thereby two separate experiments were conducted simultaneously in two different plots but enriched Sanjeevani was applied as supplementary source of plant nutrients in one sub-condition of Agnihotra farming. Thereby, two experiments were conducted under four different (two each) sub-conditions, namely $\mathrm{E}_{1} \mathrm{C}_{1}$ : Enriched Sanjeevani (1\%), and $\mathrm{E}_{1} \mathrm{C}_{2}$ : Absolute Control (Inherent Fertility Status of Experimental Soil) for Vedic Farming; and $\mathrm{E}_{2} \mathrm{C}_{1}$ : Enriched Sanjeevani (1\%) + Homa Induction (Agnihotra), and $\mathrm{E}_{2} \mathrm{C}_{2}$ : Only Homa Induction (Agnihotra) for Agnihotra Farming. Finally, field experiments were carried out through Randomized Complete Block Design by employing five varieties of brinjal, such as $V_{1}$ : Swarna Pratibha; $V_{2}$ : Swarna Neelima; $V_{3}$ : Swarna Shakti; $V_{4}$ : Mukta Jhuri; $V_{5}$ : Long Green with their four replication for each of the sub-condition of the Agnihotra and Vedic Farming. 30 days old seedlings were transplanted in 80 experimental plots each of with $3.0 \mathrm{~m} \times 2.0 \mathrm{~m}$ sizes by keeping $60 \mathrm{~cm}$ inter-row and $50 \mathrm{~cm}$ intra-row spacing. As basal application vermicompost was applied@ $@$ t ha-1 $^{-1}$ in all plots except 20 plots of $\mathrm{E}_{1} \mathrm{C}_{2}$ : Absolute Control) and liquid organic formulation (enriched Sanjeevani) was applied 5 times at 15 days interval starting from 30 days after transplanting@ 500 ml plant ${ }^{-1}$. Agnihotra mantras [at sunrise: Sooryáya swáhá sooryáya idam na mama (add the first portion of rice after Swáhá), Prajápataye swáhá prajápataye idam na mama (add the second portion of rice after Swáhá); at sunset: Agnaye swáhá agnaye idam na mama (Add the first portion of rice after Swáhá), Prajápataye swáhá Prajápataye idam na mama (add the second portion of rice after Swáhá)] were performed twice daily during morning (at sunrise) and evening (at sunset) hours as per the location specific Agnihotra calendar. As plant protection measures, Dashparni and neem leaf extract were applied 15 days interval against insect-pests as prophylactic measure, whereas, turmeric powder mixed whey water@10\% solution was sprayed at 15 days interval as against the pathogenic infection. Different growth, yield and quality attributes of the crop namely plant height $(\mathrm{cm})$, days to $50 \%$ flowering, number of fruits plant ${ }^{-1}$, average fruit weight $(\mathrm{g})$, yield $\left(\mathrm{tha}^{-1}\right)$, dry weight of fruit pulp (\%), TSS $\left({ }^{0}\right.$ Brix $)$, total sugar $(\%)$, reducing sugar $(\%)$ and ascorbic acid (mg $\left.100 \mathrm{~g}^{-1}\right)$ were taken into account and estimated as per the standard procedures (wherever applicable). Data thus obtained were subject to statistical analyses for their interpretation. Economics of organically grown brinjal was also studied by considering total cost of cultivation (Rs.), yield $\left(\mathrm{t} \mathrm{ha} \mathrm{H}^{-1}\right.$ ), farm gate price (Rs.), total income (Rs.), net profit (Rs.) and B: C ratio.

\section{RESULTS AND DISCUSSION}

Findings related to different growth and yield attributes of brinjal as influenced by different alternative approaches of farming practices viz. $\mathrm{E}_{1} \mathrm{C}_{1}$ : Enriched Sanjeevani (1\%), $\mathrm{E}_{1} \mathrm{C}_{2}$ : Absolute Control (Inherent Fertility Status of Experimental Soil); $\mathrm{E}_{2} \mathrm{C}_{1}$ : Enriched Sanjeevani (1\%) + Homa Induction (Agnihotra), and $\mathrm{E}_{2} \mathrm{C}_{2}$ : Only Homa Induction (Agnihotra) presented through Table-1. Data clearly indicated that plant 
Table 1: Per se performance of different growth and yield attributes of different brinjal varieties as influenced by alternative approaches of growing conditions

\begin{tabular}{|c|c|c|c|c|c|c|c|c|c|c|c|c|c|c|c|c|c|c|c|c|}
\hline \multirow[t]{2}{*}{ Variety } & \multicolumn{4}{|c|}{ Plant height $(\mathrm{cm})$} & \multicolumn{4}{|c|}{ Days to $50 \%$ flowering } & \multicolumn{4}{|c|}{ Number of fruits plant ${ }^{-1}$} & \multicolumn{4}{|c|}{ Average fruit weight (g) } & \multicolumn{4}{|c|}{ Yield $\left(\mathrm{t} \mathrm{ha}{ }^{-1}\right)$} \\
\hline & ${ }_{1} C_{1}$ & $\mathrm{E}_{1} \mathrm{C}_{2}$ & $\mathrm{E}_{2} \mathrm{C}_{1}$ & $\mathrm{E}_{2} \mathrm{C}_{2}$ & $\mathrm{E}_{1} \mathrm{C}_{1}$ & $\mathrm{C}_{2}$ & $\mathrm{E}_{2} \mathrm{C}_{1}$ & $\mathrm{E}_{2} \mathrm{C}_{2}$ & $\mathrm{E}_{1} \mathrm{C}_{1}$ & $\mathrm{C}_{2}$ & ${ }_{2} C_{1}$ & $\mathrm{E}_{2} \mathrm{C}_{2}$ & $\mathrm{C}_{1}$ & $\mathrm{E}_{1} \mathrm{C}_{2}$ & $\mathrm{E}_{2} \mathrm{C}_{1}$ & $\mathrm{E}_{2} \mathrm{C}_{2}$ & ${ }_{1} C_{1}$ & $\mathrm{E}_{1} \mathrm{C}_{2}$ & $\mathrm{E}_{2} \mathrm{C}_{1}$ & $\mathrm{E}_{2} \mathrm{C}_{2}$ \\
\hline & .88 & & & & 56 & & 50 & 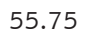 & & & & & & & & & & .78 & & \\
\hline$V_{2}$ & .19 & 39. & 60 & 53. & 60.25 & 25 & 56.75 & 6 & 00 & & & & & & & & & .35 & & \\
\hline$V_{3}$ & 5 & 38 & 52 & 43 & 64 & 73 & & 72.5 & 63 & & &  & & & & & & & & \\
\hline $\mathrm{V}_{4}$ & .38 & 43 & 35 & 39 & 73.75 & & 70 & 61.5 & 3 & & & 5.81 & & & & & & 8.59 & & \\
\hline & 36.25 & 33.60 & 34.88 & 28. & 73.5 & & & 6 & & & & & & & & & 02 & 12 & & \\
\hline SÉm & 3.42 & 27 & 2.30 & 2.6 & 2.31 & 7 & 1.81 & 3.83 & 1.49 & 7 & 9 & 0.33 & 5.86 & 1.63 & 7. & 2 & 1.62 & 1.01 & 34 & 7 \\
\hline$C D_{p}$ & 62 & 5.66 & 5.80 & 6.78 & 83 & 1 & 4.56 & NS & NS & 0.93 & NS & 0.83 & 6 & 4.09 & 19.58 & 9.84 & .07 & .53 & 9.19 & 3. \\
\hline
\end{tabular}

NS: Non-significant; $V_{1}$ : Swarna Pratibha; $V_{2}$ : Swarna Neelima; $V_{3}$ : Swarna Shakti; $V_{4}$ : Mukta Jhuri; $V_{5}$ : Long Green; $E_{1} C_{1}$ : Enriched Sanjeevani (1\%), $\mathrm{E}_{1} \mathrm{C}_{2}$ : Absolute Control (Inherent Fertility Status of Experimental Soil); $\mathrm{E}_{2} \mathrm{C}_{1}$ : Enriched Sanjeevani $(1 \%)+$ Homa Induction (Agnihotra), and $\mathrm{E}_{2} \mathrm{C}_{2}$ : Only Homa Induction (Agnihotra)

Table 2: Per se performance of different quality contributing attributes of brinjal varieties under alternative approaches of nonchemical growing condition

\begin{tabular}{|c|c|c|c|c|c|c|c|c|c|c|c|c|c|c|c|c|c|c|c|c|}
\hline \multirow[t]{2}{*}{ Variety } & \multicolumn{4}{|c|}{ Dry weight of fruit pulp (\%) } & \multicolumn{4}{|c|}{ TSS ('Brix) } & \multicolumn{4}{|c|}{ Total Sugar (\%) } & \multicolumn{4}{|c|}{ Reducing Sugar (\%) } & \multicolumn{4}{|c|}{ Ascorbic Acid (mg $\left.100 \mathrm{~g}^{-1}\right)$} \\
\hline & $\mathrm{E}_{1} \mathrm{C}_{1}$ & $\mathrm{E}_{1} \mathrm{C}_{2}$ & $E_{2} C_{1}$ & $\mathrm{E}_{2} \mathrm{C}_{2}$ & $\mathrm{E}_{1} \mathrm{C}_{1}$ & $\mathrm{E}_{1} \mathrm{C}_{2}$ & $\mathrm{E}_{2} \mathrm{C}_{1}$ & $\mathrm{E}_{2} \mathrm{C}_{2}$ & $\mathrm{E}_{1} \mathrm{C}_{1}$ & $\mathrm{E}_{1} \mathrm{C}_{2}$ & $\mathrm{E}_{2} \mathrm{C}_{1}$ & $\mathrm{E}_{2} \mathrm{C}_{2}$ & $\mathrm{E}_{1} \mathrm{C}_{1}$ & $\mathrm{E}_{1} \mathrm{C}_{2}$ & $\mathrm{E}_{2} \mathrm{C}_{1}$ & $\mathrm{E}_{2} \mathrm{C}_{2}$ & $\mathrm{E}_{1} \mathrm{C}_{1}$ & $\mathrm{E}_{1} \mathrm{C}_{2}$ & $\mathrm{E}_{2} \mathrm{C}_{1}$ & $\mathrm{E}_{2} \mathrm{C}_{2}$ \\
\hline$\overline{V_{1}}$ & 8.19 & 6.87 & 11.19 & 9.95 & 2.03 & 1.95 & 5.20 & 3.23 & 3.68 & 1.95 & 4.84 & 2.66 & 2.46 & 2.41 & 3.33 & 3.15 & 6.00 & 1.50 & 8.50 & 3.75 \\
\hline $\mathrm{V}_{2}$ & 8.24 & 6.43 & 13.04 & 9.73 & 3.03 & 2.03 & 4.30 & 3.00 & 3.20 & 2.35 & 3.97 & 3.56 & 2.61 & 2.21 & 3.04 & 3.08 & 4.00 & 2.50 & 9.00 & 5.50 \\
\hline $\mathrm{V}_{3}^{2}$ & 7.25 & 8.13 & 10.20 & 9.74 & 1.95 & 1.93 & 5.98 & 3.13 & 3.27 & 1.90 & 3.74 & 3.04 & 3.76 & 3.23 & 3.42 & 3.09 & 4.50 & 2.25 & 11.38 & 4.38 \\
\hline$V_{4}^{3}$ & 9.87 & 7.61 & 13.10 & 11.76 & 1.98 & 1.98 & 3.25 & 2.75 & 3.09 & 2.59 & 4.96 & 3.26 & 2.44 & 2.12 & 2.75 & 2.94 & 3.00 & 3.50 & 8.25 & 6.13 \\
\hline$V_{5}^{4}$ & 9.27 & 7.17 & 11.71 & 10.99 & 1.88 & 1.08 & 2.23 & 2.20 & 2.35 & 1.79 & 3.52 & 3.08 & 2.67 & 2.42 & 3.52 & 2.97 & 5.50 & 6.00 & 9.63 & 9.25 \\
\hline $\mathrm{SEm}^{5}( \pm)$ & 0.35 & 0.15 & 1.06 & 0.76 & 0.06 & 0.10 & 0.11 & 0.16 & 0.03 & 0.02 & 0.10 & 0.05 & 0.04 & 0.04 & 0.09 & 0.08 & 0.25 & 0.35 & 1.06 & 0.41 \\
\hline & 0.89 & 0.37 & NS & NS & 0.14 & 0.25 & 0.29 & 0.41 & 0.07 & 0.04 & 0.26 & 0.13 & 0.09 & 0.10 & 0.22 & NS & 0.62 & 0.88 & NS & 1.03 \\
\hline
\end{tabular}

NS: Non-significant; $V_{1}$ : Swarna Pratibha; $V_{2}$ : Swarna Neelima; $V_{3}$ : Swarna Shakti; $V_{4}$ : Mukta Jhuri; $\mathrm{V}_{5}$ : Long Green; $\mathrm{E}_{1} \mathrm{C}_{1}$ : Enriched Sanjeevani ( $1 \%$ ), $\mathrm{E}_{1} \mathrm{C}_{2}$ : Absolute Control (Inherent Fertility Status of Experimental Soil); $\mathrm{E}_{2} \mathrm{C}_{1}$ : Enriched Sanjeevani $(1 \%)+$ Homa Induction (Agnihotra), and $\mathrm{E}_{2} \mathrm{C}_{2}$ : Only Homa Induction (Agnihotra)

Table 3: Cost of cultivation of brinjal in one hectare of land under different alternative approaches of non-chemical growing conditions

\begin{tabular}{|c|c|c|c|c|}
\hline Components & $\mathrm{E}_{1} \mathrm{C}_{1}$ & $\mathrm{E}_{1} \mathrm{C}_{2}$ & $\mathrm{E}_{2} \mathrm{C}_{1}$ & $\mathrm{E}_{2} \mathrm{C}_{2}$ \\
\hline \multicolumn{5}{|l|}{ Cost $\left(A_{1}\right)$} \\
\hline Cost of hired labour for land preparation (Rs.) & 2000.00 & 2000.00 & 2000.00 & 2000.00 \\
\hline Hired labour cost for sowing and transplanting (Rs.) & 5000.00 & 5000.00 & 5000.00 & 5000.00 \\
\hline Cost of hired machinery (Rs.) & 1500.00 & 1500.00 & 1500.00 & 1500.00 \\
\hline Cost of own machinery (Rs.) & 0.00 & 0.00 & 0.00 & 0.00 \\
\hline Cost of planting material (Rs.) & 4000.00 & 4000.00 & 4000.00 & 4000.00 \\
\hline Cost of plant protection (Rs.) & 3000.00 & 3000.00 & 3000.00 & 3000.00 \\
\hline Cost of mulching (Rs.) & 2500.00 & 2500.00 & 2500.00 & 2500.00 \\
\hline Cost of manure (vermicompost) (Rs.) & 15000.00 & 0.00 & 15000.00 & 15000.00 \\
\hline Cost of enriched Sanjeevani (Rs.) & 3500.00 & 0.00 & 3500.00 & 0.00 \\
\hline Cost of performing Agnihotra (Rs.) & 0.00 & 0.00 & 2500.00 & 2500.00 \\
\hline Hired labour cost for weeding and hoeing (Rs.) & 7500.00 & 7500.00 & 7500.00 & 7500.00 \\
\hline Cost of irrigation (Rs.) & 5000.00 & 3000.00 & 5000.00 & 5000.00 \\
\hline Hired labour cost for harvesting and post-harvest operations (Rs.) & 3000.00 & 2000.00 & 3000.00 & 3000.00 \\
\hline Miscellaneous cost (Rs.) & 4000.00 & 4000.00 & 4000.00 & 4000.00 \\
\hline Total (Al) [Rs.] & 56000.00 & 34500.00 & 58500.00 & 55000.00 \\
\hline \multicolumn{5}{|l|}{ Cost $(A 2)=$ Cost $A 1+$ rent on leased in land (Rs.) } \\
\hline Rent on leased in land (Rs.) [own land] & 0.00 & 0.00 & 0.00 & 0.00 \\
\hline Total (Rs.) & 56000.00 & 34500.00 & 58500.00 & 55000.00 \\
\hline \multicolumn{5}{|l|}{ Cost $(B 1)=$ Cost $A 2+$ interest on own fixed capital (Rs.) } \\
\hline Interest on own fixed capital (Rs.) & 500.00 & 500.00 & 500.00 & 500.00 \\
\hline Total (Rs.) & 56500.00 & 35000.00 & 59000.00 & 55500.00 \\
\hline \multicolumn{5}{|l|}{ Cost $(B 2)=$ Cost $B 1+$ rental value of own land (Rs.) } \\
\hline Rental value of own land (Rs.) & 2500.00 & 2500.00 & 2500.00 & 2500.00 \\
\hline Total (Rs.) & 59000.00 & 37500.00 & 61500.00 & 58000.00 \\
\hline \multicolumn{5}{|l|}{ Cost $(C)=$ Cost B $2+$ cost of own family labour (Rs.) } \\
\hline Cost of own family labour (Rs.) & 2500.00 & 2500.00 & 2500.00 & 2500.00 \\
\hline Total (Rs.) & 61500.00 & 40000.00 & 64000.00 & 60500.00 \\
\hline
\end{tabular}




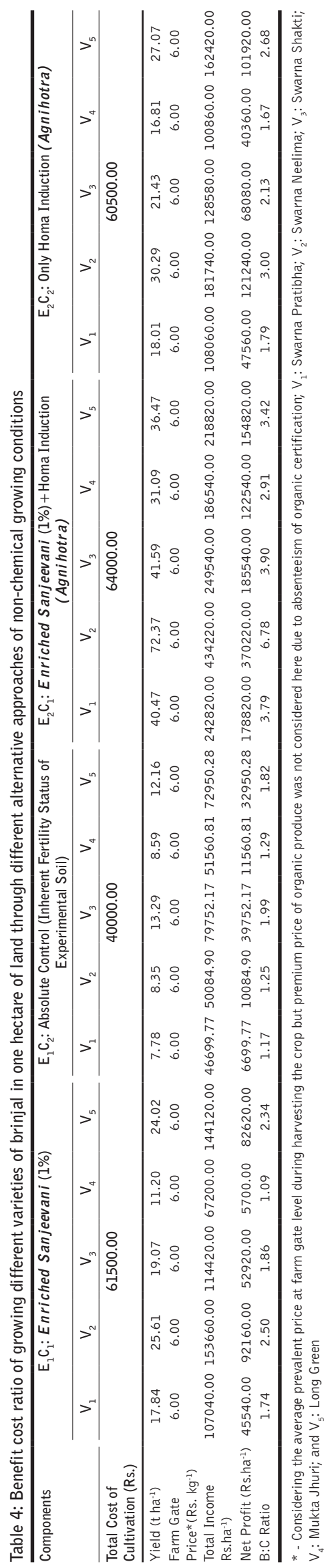

height $(\mathrm{cm})$, number of fruits plant ${ }^{-1}$, and average fruit weight $(\mathrm{g})$ recorded more in the case of $\mathrm{V}_{2}$ (Swarna Neelima) under all growing conditions (Table 1 ) resulting higher yield in all cases. However, more yield $\left(72.37 \mathrm{t} \mathrm{ha}^{-1}\right)$ recorded under $\mathrm{E}_{2} \mathrm{C}_{1}$ [Enriched Sanjeevani (1\%) + Homa Induction (Agnihotra)] followed by only $30.29 \mathrm{t} \mathrm{ha}^{-1}$ in $\mathrm{E}_{2} \mathrm{C}_{2}$ [Only Homa Induction (Agnihotra)] growing condition (Table 1). This type of findings may probably be due to the synergistic impact of the integration of organic farming and Homa farming as Homa Jaivik Krishi (Pathak, 2009) and the higher level of yield as recorded here close conformity with the earlier observation of Kumar et al. (2017) where they observed better growth and yield in okra grown through Homa Organic treatments. Besides, in homa farming condition the chlorophyll of the plants are increased, and those are the main cause of the faster growth and yield maximization (Berk and Jhonson, 2009).

Quality contributing traits were also significantly influenced by Vedic and Agnihotra farming with more dry matter content $(13.10 \%)$ in $\mathrm{E}_{2} \mathrm{C}_{1}$ : Enriched Sanjeevani $(1 \%)+$ Homa Induction (Agnihotra), followed by $11.76 \%$ as recorded in $\mathrm{E}_{2} \mathrm{C}_{2}$ : Only Homa Induction (Agnihotra) in the case of $\mathrm{V}_{4}$ (Mukta Jhuri) (Table 2). Other qualitative attributes were also greatly influenced by the Vedic and Agnihotra Farming over the absolute control and findings revealed significant effect of Agnihotra farming over TSS ( $\left.{ }^{\circ} \mathrm{Brix}\right)$, reducing sugar $(\%)$, total sugar $(\%)$ and ascorbic acid $\left(\mathrm{mg} 100 \mathrm{~g}^{-1}\right)$ than respective other counterparts (Table 2). Such findings especially in the case of homa induction (Agnihotra Farming) clearly supported the capability of homa farming on enhancing rhizosphere and biosphere simultaneously (Pathak and Ram, 2010) and higher level of ascorbic acid in homa induced growing conditions as recorded in the present investigation corroborated well with the previous findings of Kumar et al. (2017).

Economics of brinjal cultivation through non-chemical approaches of different growing condition highlighted that total cost of cultivation in one hectare of land as recorded here as Rs.61500.00 ( $\left.\mathrm{E}_{1} \mathrm{C}_{1}\right)$, Rs. $40000.00\left(\mathrm{E}_{1} \mathrm{C}_{2}\right)$, Rs. $64000.00\left(\mathrm{E}_{2} \mathrm{C}_{1}\right)$ and Rs. $60500.00\left(\mathrm{E}_{2} \mathrm{C}_{2}\right)$ (Table 3). In case of $\mathrm{E}_{1} \mathrm{C}_{1}$ the highest $\mathrm{B}: \mathrm{C}$ ratio was recorded in $\mathrm{V}_{2}(2.50)$ whereas in case of $\mathrm{E}_{1} \mathrm{C}_{2}$, the highest $\mathrm{B}$ :C ratio documented in $\mathrm{V}_{3}(1.99)$, in case of $\mathrm{E}_{2} \mathrm{C}_{1}$ the best $\mathrm{B}: \mathrm{C}$ ratio recorded in $\mathrm{V}_{2}(6.78)$ while the alternative approach of $\mathrm{E}_{2} \mathrm{C}_{2}$ growing condition showed that the highest $\mathrm{B}: \mathrm{C}$ ratio in $\mathrm{V}_{2}(3.00)$ and almost all varieties showed their best in the alternative approach of growing condition $\mathrm{E}_{2} \mathrm{C}_{1}[$ Enriched Sanjeevani (1\%) + Homa Induction (Agnihotra)] (Table 4). The findings also revealed that almost all alternative approaches of non-chemical growing approaches performed significantly well over the respective absolute control counterpart (Table 4).

\section{CONCLUSION}

From the above findings, it can be concluded that the alternative growing condition $\mathrm{E}_{2} \mathrm{C}_{1}$ [Enriched Sanjeevani $(1 \%)+$ Homa Induction (Agnihotra)] showed the better result in terms of the yield as well as the quality traits expression. In this context, the yield of $V_{2}$ (Swarna Neelima) in the alternative growing 
condition of $\mathrm{E}_{2} \mathrm{C}_{1}$ recorded the maximum yield $\left(72.37 \mathrm{tha}^{-1}\right)$ over rest of the varieties under consideration. As a consequence, the highest B:C ratio 6.78 was recorded in $V_{2}$ (Swarna Neelima) in the case of the alternative approach of $\mathrm{E}_{2} \mathrm{C}_{1}$ [Enriched Sanjeevani $(1 \%)+$ Homa Induction (Agnihotra) ] growing condition From this finding, it may be concluded that the variety $V_{2}$ (Swarna Neelima) is highly suitable for the organic farming through the alternative growing condition of $\mathrm{E}_{2} \mathrm{C}_{1}$ [Enriched Sanjeevani (1\%) + Homa Induction (Agnihotra) ] in the south Chhotanagpur plateau of eastern India especially in Jharkhand.

\section{ACKNOWLEDGEMENT}

This is an individual research but I could never have reached the heights or explored the depths without the help, support, guidance and efforts of a lot of people. This research work was financially supported by the host institute itself and the authors express their deepest sense of gratitude to the concerned authority of the institute for financial assistance towards accomplishing the experiment in its organic experimental plots located at the of Ramakrishna Mission Ashrama, Morabadi, Ranchi, Jharkhand (India) and Ramakrishna Mission Vivekananda Educational and Research Institute, Morabadi, Ranchi, Jharkhand (India).

\section{REFERENCES}

Patil SB, Merwade MN, Vyakaranahal BS, Deshpande VK. Effect of pollination time and crossing ratio on seed yield and quality of brinjal hybrid under Dharwad region of Karnataka. Indian Journal of Agricultural Research. 2008;42(1):7-12.

Sharon, N. L., and Nishanthlalu, G. A. A Study on Effects of Chemical Farming On Farmers At Kilkundaiyar Village, Thiruvallur District, Tamil Nadu. 2014.

Berk, U. and Jhonson, B. Bringing Homa farming in to mainstream of Indian Agriculture System. Five Fold Path Publication, Dhule, Maharashtra. 2009.

Kumar R, Kumar A, Chakraborty S, Basarkar PW. Effect of Homa organic farming on growth, yield and quality parameters of Okra. Journal of Applied and Natural Science. 2017 Dec 1;9(4):2205-10.

Ram RA, Pathak RK. Organic Approaches for sustainable production of horticultural crops: A review. Progressive Horticulture. 2016 Jun;48(1):1.Pathak, R. K. and Ram, R.A. 2009. Manual on Organic Farming in Horticultural Crops, CISH, Lucknow.

Singh SR. Effect of organic farming system on yield and quality of Brinjal (Solanum melongena L) var Pusa Purple Cluster under mid-hill conditions of Himachal Pradesh. Haryana Journal of Horticultural Sciences. 2004;33(3/4):265-6.

Ullah MS, Islam MS, Islam MA, Haque T. Effects of organic manures and chemical fertilizers on the yield of brinjal and soil properties. Journal of the Bangladesh Agricultural University. 2008;6(2):271-6.

Mahto SK, Dutta AK. Influence of different low-cost organic inputs on growth, yield and quality of French bean (Phaseolus vulgaris L.) cv. Swarna Priya. Indian Journal of Agricultural Research. 2018 Dec 1;52(6). 